Mariola Szewczyk-Jarocka, Accepted: 01.09.2020

Mazowiecka Uczelnia Publiczna w Płocku

\title{
UNDECLARED WORK OF SOCIALLY EXCLUDED PEOPLE IN LIGHT OF SURVEY RESEARCH
}

Undeclared work is conducted without entering into an official employment relationship. The aim of the research is to present opinions of respondents on the local labor market about work performed outside of an actual contract by socially excluded people. The analysis was conducted using a survey of the opinions of socially excluded people registered at the Municipal Labor Office in the city of Plock. The analysis included the results of surveys received from 350 respondents, including 195 people surveyed using paper questionnaires and 155 people surveyed using a questionnaire posted on the Internet in 2018. The analyses included the distribution of answers to survey question within the entire sample together with verification of the statistical significance between the answers and such variables as: sex, age, education and period of being registered in the Municipal Employment Office.

Keywords: undeclared work, socially excluded people, opinion surveys JEL codes: E24, E26, J46

\section{Introduction}

Undeclared or unregistered work is conducted without entering into an official employment relationship. The most important motives for undertaking research on undeclared work included the following premises:

- willingness to diagnose the advantages of registered work,

- raising public awareness of the undeclared labor market.

Given the above premises, the main purpose of the research was to attempt to determine the advantages of undeclared work (performed outside of registration) including the work of socially excluded people.

The gathering of information on the abovementioned issues was primarily supported by an empirical study designed and conducted by the author of the article. A survey of the opinions of socially excluded people registered at the Municipal Labor Office in the city of Plock was used. It was a deliberately selected population of 350 respondents, including 195 people surveyed using paper questionnaires and 155 people surveyed using a questionnaire posted on the Internet in 2018.

The aim of the research was:

1. Understanding the benefits of working outside of registration.

2. Determining the advantages of undeclared work in a group of socially excluded people.

\section{Material and research methodology}

Based on the data collected during the research, the author attempted to get answers to the research questions: 
- What are the advantages of undeclared work?

- What are the advantages of undeclared work for socially excluded people?

A survey of the literature on the subject and the author's empirical research through questionnaires were the approaches used in the study. Research was conducted under a portion of a grant from the Plock City Hall - within the task of "Cooperation with universities". The research covered 350 unemployed persons registered at the Municipal Labor Office in Plock. Statistical tests and descriptive methods were used. The results are presented in tabular, graphic and descriptive form.

\section{The concept of social exclusion}

The term social exclusion in the modern sense probably was used for the first time in $\mathrm{R}$. Lenoir's 1974 publication "Les exclus", to describe people who do not participate in either social or economic development (Broda - Wysocki, 2012).

As defined in the National Integration Strategy for Poland, social exclusion is "the lack or limitation of participation, influence and use of basic public institutions and markets that should be available to everyone, especially the poor", i.e. a situation preventing or significantly hindering an individual or a group from fulfilling the lawful social roles, using public goods and infrastructure, gathering resources and earning income in a dignified manner "(Frąckiewicz, 2005).

In general, the concept of social exclusion contains three important dimensions (Sobczak, 2016):

1. exclusion from the labor market and loss of social ties;

2. loss of participation, e.g. due to lack of financial resources;

3 . in the statistical sense, exclusion is a series of progressive changes or restrictions in the possibilities of participating in economic, political, cultural or social life; it is not an irreversible process.

\section{Definition of unregistered (undeclared) work}

Unregistered work (work in the gray economy, sometimes the black market) is a collective category covering various ways of participation and activity on the labor market. Unlike registered work, it has the following characteristics (Metodologia ..., 2005):

1. It is employment performed without establishing an employment relationship, i.e. without an employment contract or other written contract between the employee and the employer. The employee does not obtain social insurance, does not pay taxes on personal income, and the employer also does not pay contributions to the account of the Social Insurance Institution and the Labor Fund;

2. It can also be self-employment if no taxes or social security contributions or other financial obligations are owed to the state for business operations.

Poland is one of the few countries where in-depth empirical research is conducted on the role of undeclared work in the economy. The first study was undertaken in 1995 and covered over 11,000 households, which meant a population of over 25.6 thousand persons aged 15 and older (Unregistered work, 1995). The second survey was carried out in 1998 and also covered 11,000 households (over 25,000 people aged 15 and older) (Unregistered work, 1998). The third survey was carried out in 2004 (Unregistered work, 2010). In addition, a report was prepared in 2008 at the request of the Labor Market Department of the Ministry of Labor and Social Policy on "Reasons for unregistered 
work, its scale, nature and social effects" (Reasons for unregistered work, 2008). Research on unregistered work is being conducted with some regularity and the author's research is part of this trend.

Unregistered work is usually undertaken by people with lower qualifications and levels of education, as well as by immigrants from countries with low wages (resulting from both the level of economic development and differences in the purchasing power of currencies). The existence of a shadow economy in the economy is usually a response to high labor costs, high unemployment, difficult labor market, bureaucratic burdens on doing business. The famous "tax wedge", or almost two times the difference between what an employee gets "in hand" and the costs incurred by the employer due to his/her employment, is an incentive to pay the employee all or part of the remuneration in an informal, unregistered manner. Due to bureaucratic burden, high taxes and social security contributions, many people work without registration. Although this significantly increases the number of jobs, it is certainly not a driver of socioeconomic progress. It is rather a method of survival for both employers and employees who have no chance on the official labor market.

\section{Advantages of working outside of registration in light of the author's research}

Working without officially registering employment is carried out without establishing an employment relationship under an employment contract or mandate contract. As already mentioned, the survey results concern a population of 350 respondents, including 195 people surveyed using paper questionnaires and 155 people surveyed using a questionnaire posted on the Internet (Szewczyk-Jarocka, 2019).

The analyses covered the responses of the respondents in total in the entire sample and verification of the statistical significance of the relationship between the answers and the sex, age, education and length of the registration period at the Municipal Labor Office.

Table 1. Evaluation of the advantages of taking unregistered work

\begin{tabular}{|l|c|c|c|c|}
\hline \multicolumn{1}{|c|}{ Advantages } & $\boldsymbol{M}$ & $\boldsymbol{S D}$ & $\min$ & $\max$ \\
\hline Source of livelihood & $\mathbf{4 . 1 7}$ & 1.78 & 1 & 6 \\
\hline Neutralization of the effects of unemployment & 3.09 & 1.66 & 1 & 6 \\
\hline Protection against loss of qualifications & 2.94 & 1.70 & 1 & 6 \\
\hline A chance to gain new qualifications & 3.43 & 1.78 & 1 & 6 \\
\hline Poverty reduction & $\mathbf{4 . 0 0}$ & 1.79 & 1 & 6 \\
\hline Weaker pressure on using social assistance & 3.16 & 1.74 & 1 & 6 \\
\hline Promoting the integration of the unemployed & 2.91 & 1.62 & 1 & 6 \\
\hline $\begin{array}{l}\text { Source of raising capital, which may lead to legalization of operations } \\
\text { in the future }\end{array}$ & 3.32 & 1.71 & 1 & 6 \\
\hline Type of initial selection of job candidates & & & & \\
\hline Operating cost reduction & 2.91 & 1.63 & 1 & 6 \\
\hline Increasing the competitiveness of companies on product markets & 3.87 & 1.70 & 1 & 6 \\
\hline Improving the financial condition of households & 3.15 & 1.53 & 1 & 6 \\
\hline Increasing global demand & $\mathbf{4 . 0 9}$ & 1.62 & 1 & 6 \\
\hline Payment of indirect taxes & 2.92 & 1.45 & 1 & 6 \\
\hline Unemployment reduction & 3.02 & 1.57 & 1 & 6 \\
\hline
\end{tabular}

$M$ - average value; $S D$ - standard deviation; min - minimum value; max - maximum value

Source: Author's own research based on a survey. 
The value of 0.05 was conventionally assumed as the statistical significance threshold. The statistical significance of the analyzed relationships was tested based on the likely ratio values. Selected data are presented in tables and charts. Table 1 presents descriptive statistics for assessing the benefits of taking unregistered work.

The highest values were obtained for treating unregistered work as a means of subsistence, a means of improving financial condition and reducing poverty.

Table 2 presents the values of the Mann-Whitney $U$ test, which was used to analyze the statistical significance of gender differences in the obtained scores.

Table 2. Analysis of the statistical significance of gender differences in the assessment of the advantages of undeclared work

\begin{tabular}{|l|c|c|}
\hline \multicolumn{1}{|c|}{ Advantages } & $\boldsymbol{U}$ & $\boldsymbol{p}$ \\
\hline Source of livelihood & 11320.00 & 0.161 \\
\hline Neutralization of the effects of unemployment & 11013.00 & 0.066 \\
\hline Protection against loss of qualifications & 11846.50 & 0.924 \\
\hline A chance to gain new qualifications & 11397.50 & 0.197 \\
\hline Poverty reduction & $\mathbf{9 3 0 4 . 5 0}$ & $\mathbf{0 . 0 0 1}$ \\
\hline Weaker pressure on using social assistance & $\mathbf{1 0 4 7 9 . 0 0}$ & $\mathbf{0 . 0 1 5}$ \\
\hline Promoting the integration of the unemployed & 12123.50 & 0.688 \\
\hline $\begin{array}{l}\text { Source of raising capital, which may lead to legalization of operations in the } \\
\text { future }\end{array}$ & 12321.50 & 0.820 \\
\hline Type of initial selection of job candidates & 11186.50 & 0.360 \\
\hline Operating costs reduction & 11228.50 & 0.390 \\
\hline Increasing the competitiveness of companies on product markets & 11312.50 & 0.452 \\
\hline Improving the financial condition of households & $\mathbf{1 0 1 5 5 . 5 0}$ & $\mathbf{0 . 0 2 6}$ \\
\hline Increasing global demand & 10748.50 & 0.508 \\
\hline Payment of indirect taxes & 11166.00 & 0.918 \\
\hline Unemployment reduction & 10262.00 & 0,71 \\
\hline
\end{tabular}

$U$ - Mann-Whitney $\mathrm{U}$ test value; $p$ - two-sided statistical significance

Source: Author's own research based on a survey.

Statistically significant differences were obtained between men and women as to the assessment of the benefits of unregistered work, such as poverty reduction, weakening the pressure on using social assistance and improving the financial condition of households. The average frequency assessment values obtained in the group of women were higher than the values obtained in the group of men (see Figure 1). 


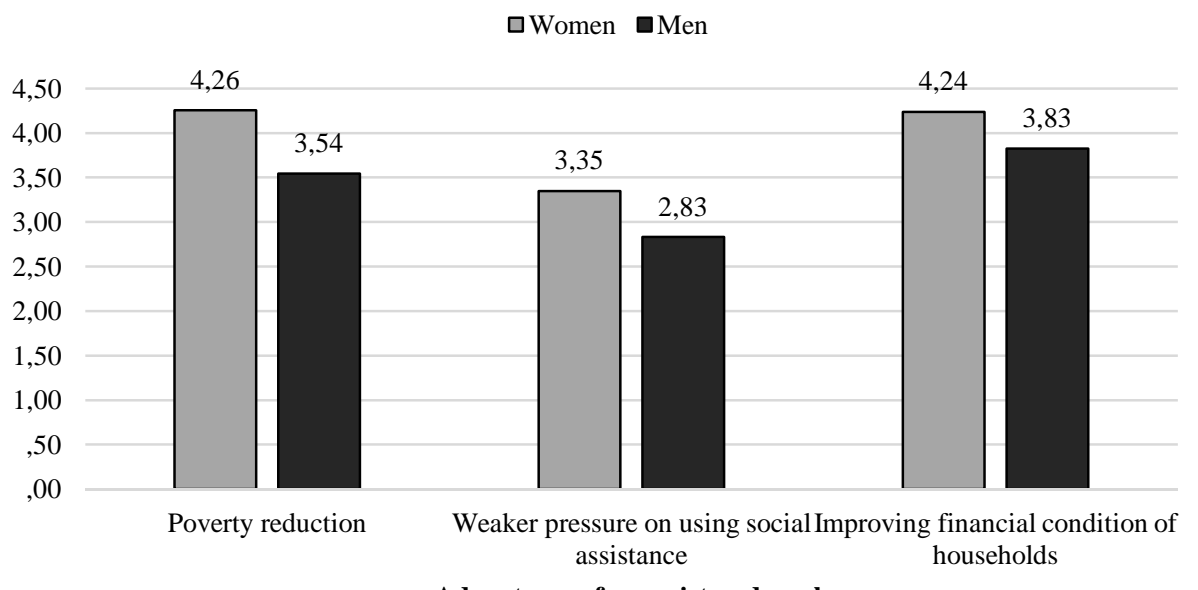

Advantages of unregistered work

Figure 1. Statistically significant differences between the sexes regarding the advantages of unregistered work Source: Author's own research based on a survey.

Table 3. Analysis of statistical significance of gender differences in the assessment of the advantages of unregistered work depending on the education level of the respondents

\begin{tabular}{|l|l|l|}
\hline \multicolumn{1}{|c|}{ Advantages } & \multicolumn{1}{c|}{$\boldsymbol{\chi}^{\mathbf{2}}$} & \multicolumn{1}{c|}{$\boldsymbol{p}$} \\
\hline Source of livelihood & $\mathbf{1 2 . 7 1}$ & $\mathbf{0 . 0 0 2}$ \\
\hline Neutralization of the effects of unemployment & $\mathbf{1 1 . 3 4}$ & $\mathbf{0 . 0 0 3}$ \\
\hline Protection against loss of qualifications & 0.32 & 0.851 \\
\hline A chance to gain new qualifications & 3.98 & 0.137 \\
\hline Poverty reduction & $\mathbf{9 . 2 6}$ & $\mathbf{0 . 0 1 0}$ \\
\hline Weaker pressure on using social assistance & 4.18 & 0.124 \\
\hline Promoting the integration of the unemployed & 0.15 & 0.927 \\
\hline $\begin{array}{l}\text { Source of raising capital, which may lead to legalization of operations in the } \\
\text { future }\end{array}$ & 1.83 & 0.401 \\
\hline Type of initial selection of job candidates & & \\
\hline Operating costs reduction & 0.78 & 0.678 \\
\hline Increasing the competitiveness of companies on product markets & $\mathbf{2 2 . 4 6}$ & $\mathbf{0 . 0 0 1}$ \\
\hline Improving the financial condition of households & 5.63 & 0.060 \\
\hline Increasing global demand & $\mathbf{6 . 2 3}$ & $\mathbf{0 . 0 4 4}$ \\
\hline Payment of indirect taxes & 1.13 & 0.569 \\
\hline Unemployment reduction & 3.65 & 0.161 \\
\hline
\end{tabular}

$\chi^{2}-$ Kruskall-Wallis $\mathrm{H}$ test value; $p$ - two-sided statistical significance

Source: Author's own research based on a survey.

Table 3 presents the values of the Kruskall-Wallis $H$ test, which was used to analyze the statistical significance of intergroup differences in the received grades depending on the level of education of the respondents.

Statistically significant intergroup differences were obtained in terms of assessments of unregistered work as a source of income, a measure to neutralize the effects of unemployment, reduce poverty, reduce operating costs, improve the financial condition of households, and reduce unemployment.

The average values obtained in the group of people without secondary education were lower than in the group of people with higher education. This applies to assessments of 
unregistered work as a source of income, $U=3779.00, \mathrm{p}<0.001$; measure to neutralize the effects of unemployment, $\mathrm{U}=3935.50, \mathrm{p}<0.01$; poverty reduction, $\mathrm{U}=4019.50$, $\mathrm{p}<0.01$; operating cost reduction, $\mathrm{U}=3035.50, \mathrm{p}<0.001$; improving the financial condition of households, $\mathrm{U}=3957.00, \mathrm{p}<0.05$; and unemployment reduction, $\mathrm{U}=3900.00, \mathrm{p}<0.05$.

It was also found that the rating for lowering operating costs was lower in the group of people with secondary education than in the group of people with higher education, $\mathrm{U}=5429.00, \mathrm{p}<0.05$. For some assessments, the average values obtained in the group of people with secondary education were higher than the average values obtained in the group of people without secondary education. This applies to assessments of unregistered work as a means of neutralizing the effects of unemployment, $\mathrm{U}=4878.00, \mathrm{p}<0.05$; poverty reduction, $\mathrm{U}=4693.50, \mathrm{p}<0.05$; operating cost reduction, $\mathrm{U}=4533.50, \mathrm{p}<0.05$; and unemployment reduction, $\mathrm{U}=4244.00, \mathrm{p}<0.05$ (see Figure 2).

Education

$\square$ higher $\square$ secondary $\square$ below secondary

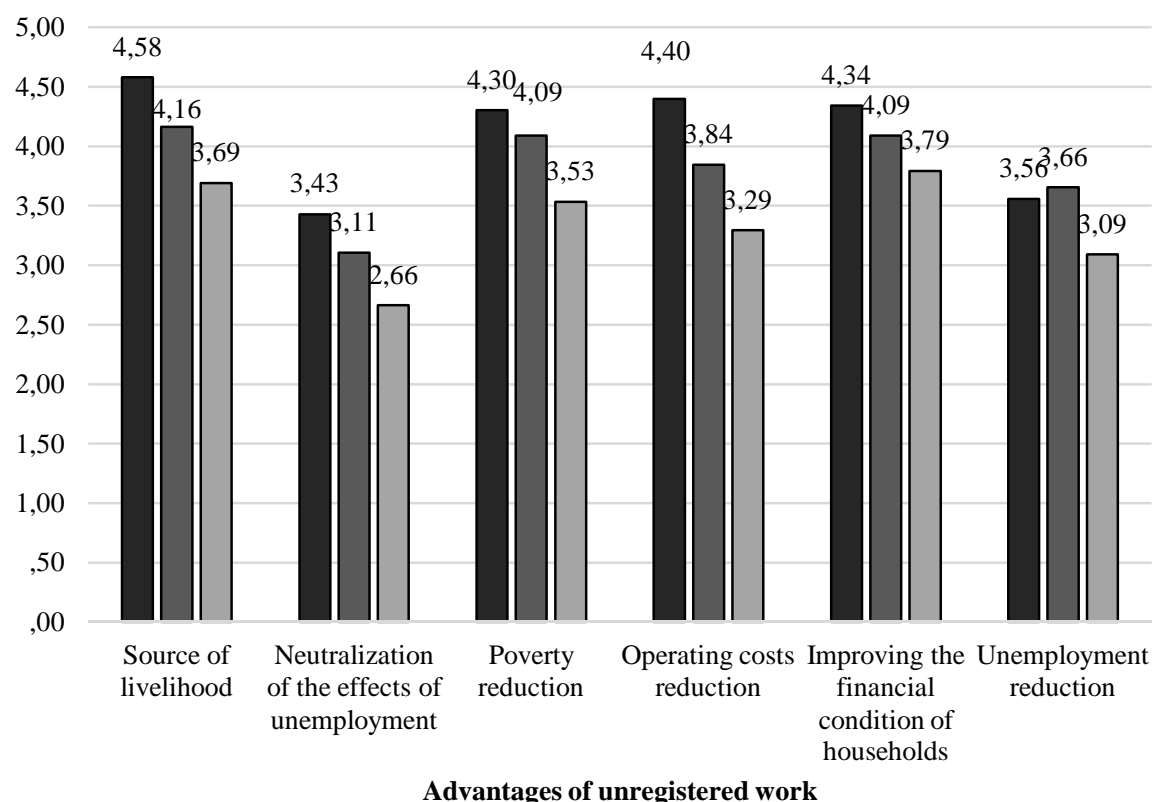

Figure 2. Statistically significant differences between the sexes regarding the advantages of unregistered work depending on the education of the respondents

Source: Author's own research based on a survey.

Table 4 presents the values of the Mann-Whitney U test, which was used to analyze the statistical significance of intergroup differences in the range of ratings obtained depending on the age of the researched. 
Table 4. Analysis of the statistical significance of gender differences as to the merits of unregistered work depending on the age of the respondents

\begin{tabular}{|l|l|l|}
\hline \multicolumn{1}{|c|}{ Advantages } & \multicolumn{1}{|c|}{$\boldsymbol{U}$} & \multicolumn{1}{c|}{$\boldsymbol{p}$} \\
\hline Source of livelihood & 11394.50 & 0.085 \\
\hline Neutralization of the effects of unemployment & $\mathbf{1 0 5 0 9 . 0 0}$ & $\mathbf{0 . 0 0 4}$ \\
\hline Protection against loss of qualifications & 12450.00 & 0.970 \\
\hline A chance to gain new qualifications & 11395.00 & 0.081 \\
\hline Poverty reduction & 12333.50 & 0.709 \\
\hline Weaker pressure on using social assistance & 12103.00 & 0.397 \\
\hline Promoting the integration of the unemployed & $\mathbf{1 1 0 1 3 . 0 0}$ & $\mathbf{0 . 0 2 7}$ \\
\hline $\begin{array}{l}\text { Source of raising capital, which may lead to legalization of operations in the } \\
\text { future }\end{array}$ & 11400.50 & 0.071 \\
\hline Type of initial selection of job candidates & & \\
\hline Operating cost reduction & 11543.00 & 0.396 \\
\hline Increasing the competitiveness of companies on product markets & $\mathbf{1 0 2 5 0 . 0 0}$ & $\mathbf{0 . 0 1 3}$ \\
\hline Improving the financial condition of households & 11106.00 & 0.162 \\
\hline Increasing global demand & 11029.50 & 0.136 \\
\hline Payment of indirect taxes & 10040.50 & 0.081 \\
\hline Unemployment reduction & 9957.50 & 0.065 \\
\hline
\end{tabular}

$U$ - Mann-Whitney U test value; $p$ - two-sided statistical significance

Source: Author's own research based on a survey.

Statistically significant inter-group differences were obtained in terms of assessments received for neutralizing the effects of unemployment, promoting integration of the unemployed, operating cost reduction and unemployment reduction. The average values of grades obtained in the younger age group were higher than the values obtained in the older age group (see Figure 3 ).

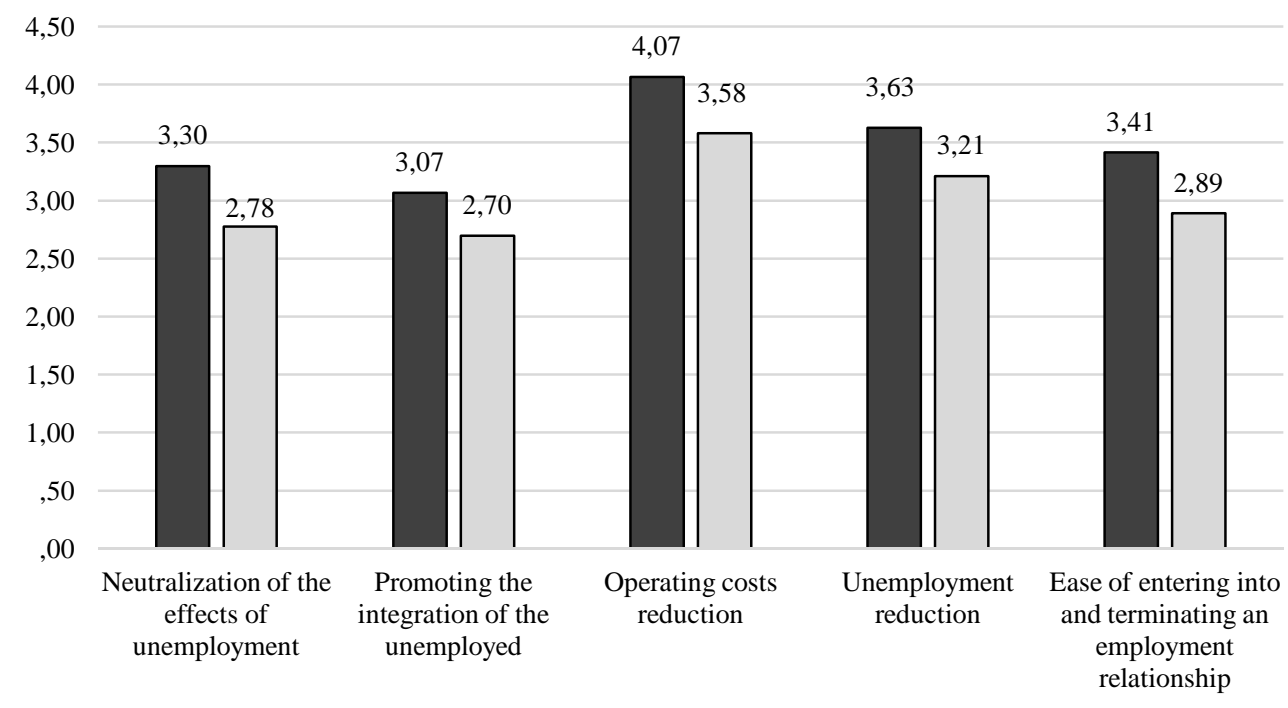

Advantages of unregistered work

Figure 3. Statistically significant differences by gender as to the merits of unregistered work depending on the age of the respondents

Source: Author's own research based on a survey. 
Table 5 presents the values of the Mann-Whitney U test, which was used to analyze the statistical significance of intergroup differences in the range of ratings obtained depending on the length of the registration period at the Municipal Labor Office.

Table 5. Analysis of the statistical significance of gender differences in the assessment of the advantages of unregistered work depending on the length of the registration period at the Municipal Labor Office

\begin{tabular}{|l|c|c|}
\hline \multicolumn{1}{|c|}{ Advantages } & $\boldsymbol{U}$ & $\boldsymbol{p}$ \\
\hline Source of livelihood & 12197.00 & 0.344 \\
\hline Neutralization of the effects of unemployment & 11832.50 & 0.144 \\
\hline Protection against loss of qualifications & 12527.50 & 0.973 \\
\hline A chance to gain new qualifications & 11909.00 & 0.199 \\
\hline Poverty reduction & 12556.50 & 0.756 \\
\hline Weaker pressure on using social assistance & 12783.00 & 0.819 \\
\hline Promoting the integration of the unemployed & 12581.00 & 0.657 \\
\hline Source of raising capital, which may lead to legalization of operations in the future & 12846.50 & 0.815 \\
\hline Type of initial selection of job candidates & 11431.00 & 0.176 \\
\hline Operating cost reduction & 11244.00 & 0.114 \\
\hline Increasing the competitiveness of companies on product markets & 12242.50 & 0.737 \\
\hline Improving the financial condition of households & 12340.00 & 0.830 \\
\hline Increasing global demand & 11325.00 & 0.579 \\
\hline Payment of indirect taxes & $\mathbf{1 0 0 6 6 . 5 0}$ & $\mathbf{0 . 0 2 8}$ \\
\hline Unemployment reduction & 10874.50 & 0.224 \\
\hline
\end{tabular}

$U$ - Mann-Whitney U test value; $p$ - two-sided statistical significance

Source: Author's own research based on a survey.

A statistically significant difference was obtained in the assessment of indirect taxes. The average value of frequency ratings obtained in the group of people registered for up to 3 months was higher than the value obtained in the group of people registered for a longer period (see Figure 4).

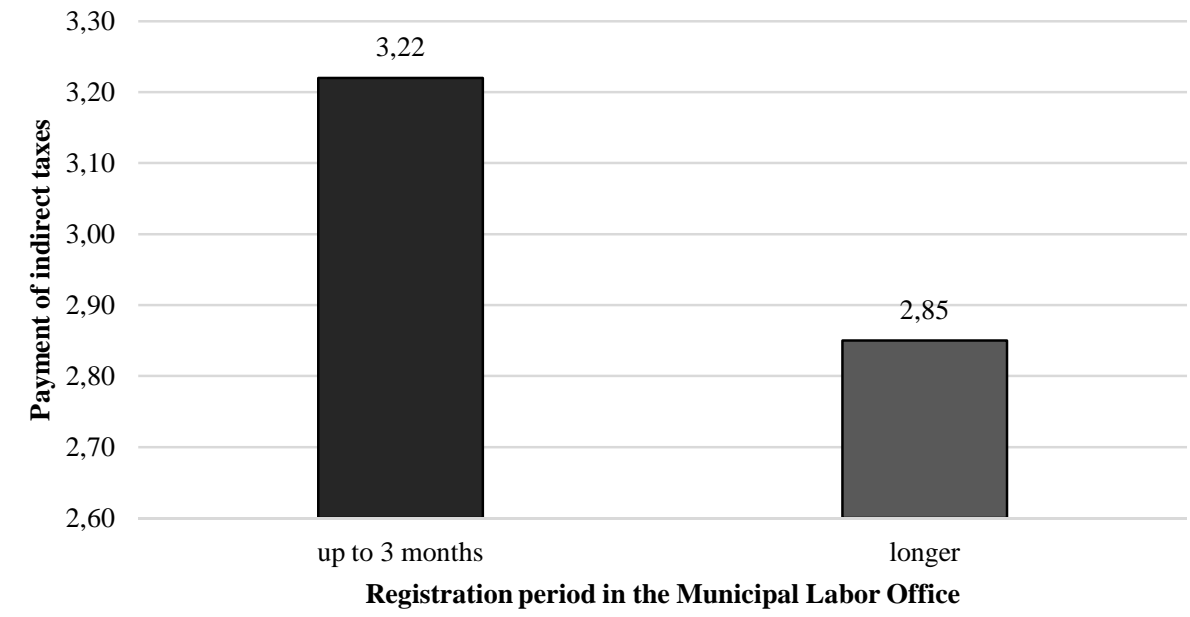

Figure 4. Evaluation of paying indirect taxes as an advantage of unregistered work depending on the length of the registration period in the Municipal Labor Office

Source: Author's own research based on a survey. 


\section{Conclusion}

Undeclared or unregistered work is often undertaken by socially excluded people. It is conducted without establishing an official employment relationship, i.e. without an employment contract or mandate contract.

The author analyzed selected advantages of performing such work according to the assessment of a group of unemployed persons who were registered with the Municipal Labor Office in Plock. Opinion diversity was presented in the researched group by sex, education level, age and period of registration in the Municipal Labor Office. Depending on the group, various advantages of work performed outside the registration of socially excluded people were indicated. Reducing poverty, weakening the emphasis on using social assistance and improving the financial condition of households are the main advantages of working outside of registration mentioned more often by women than men. Assessment of unregistered work as a source of income, a measure to neutralize the effects of unemployment, reduce poverty, reduce operating costs, improve the financial condition of households and reduce unemployment are the main advantages of working outside of registration mentioned by persons with higher and secondary education. Neutralization of the effects of unemployment, favoring the integration of the unemployed, reducing operating costs and limiting unemployment are the main advantages of unregistered work mentioned by the surveyed people aged up to 35 years and 36+. Transferring indirect taxes is the main advantage of working unregistered according to the respondents registered in the Municipal Labor Office.

To sum up, unregistered or undeclared work, on the one hand, reduces poverty and the emphasis on the use of social assistance benefits, but on the other hand, in the long run, people working without registration lose their entitlement to a pension or retirement, which is a noticeable serious problem for these people.

\section{Source of data use}

Scientific and research work called "Social inclusion of socially excluded people working in the shadow economy as a driving force of entrepreneurship development in Plock" was conducted under a grant - in accordance with an Agreement No. 20 WEKI / Z / 1383/2018 of June 15, 2018 concluded between the Commune and the City of Plock, and the State Higher Vocational School in Plock and an Agreement No. 20 / WEK-I / Z / 607/2019 of March 15, 2019 concluded between the Municipality of the City of Plock and the State Higher Vocational School in Plock.

\section{Bibliography}

Broda-Wysocki P., 2012: Wykluczenie i inkluzja społeczna. Paradygmaty i próby definicji. IPiSS, Warszawa, s. 25.[Social exclusion and inclusion. Paradigms and definition attempts. IPiSS, Warsaw, p. 25]

Frąckiewicz L. (Red.), 2005:Wykluczenie społeczne, Wydawnictwo Akademii Ekonomicznej im. Karola Adamieckiego, Katowice, s. 11[Social exclusion, publisher of the University of Economics of Karol Adamiecki, Katowice, p. 11].

Smuga T. (Red.), 2005:Metodologia badań szarej strefy na rynku usług turystycznychInstytut Koniunktur i Cen Handlu Zagranicznego, Warszawa/Gray market research methodology on the tourist services market Institute of Foreign Trade Pricing and Prices, Warsaw]. 
Praca nierejestrowana w Polsce w 1995 r., 1996: Informacje i opracowania statystyczne, Warszawa/Unregistered work in Poland in 1995, 1996: Statistical information and studies, Warsaw].

Praca nierejestrowana w Polsce w 1998 r., 1999, praca zespołowa pod kierunkiem S. Kostrubiec, GUS, Informacje i opracowania statystyczne, Warszawa/Unregistered work in Poland in 1998, 1999, teamwork under the direction of S. Kostrubiec, Central Statistical Office, Statistical information and studies, Warsaw].

Praca nierejestrowana w Polsce w 2010 r., 2011, praca zespołowa pod kierunkiem A. Zgierska, GUS, Informacje i opracowania statystyczne, Gdańsk/Unregistered work in Poland in 2010, 2011, teamwork under the direction of A. Zgierska, Central Statistical Office, Statistical information and studies, Gdańsk].

Przyczyny pracy nierejestrowanej, jej skala, charakter i skutki społeczne pod red. $M$. Bednarskiego, E. Kryńskiej, K. Patera, M. Walewskiego.2008. Raport przygotowany nazlecenie Departamentu Rynku Pracy Ministerstwa Pracy i Polityki Społecznej w ramach projektu „Przyczyny pracy nierejestrowanej, jej skala, charakter i skutki społeczne” współfinansowanego ze środków Europejskiego Funduszu Społecznego. Wykonawcy projektu: Instytut Badań i Spraw Socjalnych, Centrum Badania Opinii Społecznej (CBOS), CASE - Centrum Analiz Społeczno Ekonomicznych Millward - Brown SMG/ KRC, Warszawa/Reasons for undeclared work, its scale, nature and social effects, edited by M. Bednarski, E. Kryńska, K. Pater, M. Walewski. 2008. Report prepared at the request of the Labor Market Department of the Ministry of Labor and Social Policy as part of the project 'Reasons for undeclared work, its scale, nature and social effects' co-financed by the European Social Fund. Project contractors: Institute for Research and Social Affairs, Public Opinion Research Center (CBOS), CASE - Millward Socio-Economic Analysis Center - Brown SMG / KRC, Warsaw].

Sobczak M. J., 2016:Wykluczenie społeczne i inkluzja społeczna z wykorzystaniem podmiotów ekonomii społecznej w Polsce na przykładzie województwa łódzkiego.Wydawnictwo Uniwersytetu Łódzkiego,Łódź, s. 15[Social exclusion and social inclusion using social economy entities in Poland on the example of the Lodz region. University of Łódź Publishing House, Łódź, p. 15$]$.

Szewczyk-Jarocka M., 2019: Social inclusion of individuals suffering from exclusion - evaluation of motives and actions in view of own research. Acta Scientarium Polonorum 18 (1), Warszawa, s. 81-89[Warsaw, p. 81-89].

Szewczyk - Jarocka M., 2019: Job counseling a tool for social inclusion: empirical research in Poland. Economic Science for Rural Development 2019, Latvia, p. 188 - 193.

Szewczyk - Jarocka M., 2019: Opinions of socially excluded individuals on conducting business activity and being employed on a full-time basis in view of own research, Research Papers of Wrocław University of Economics, 2019 vol. 63 nr 5, Wrocław, p. 90 - 101.

\section{Nierejestrowana praca osób wykluczonych społecznie w świetle badań ankietowych}

\section{Streszczenie}

Praca nierejestrowana jest wykonywana bez nawiązania oficjalnego stosunku pracy. Celem badania jest przedstawienie opinii respondentów na lokalnym rynku pracy na temat pracy wykonywanej poza faktycznym kontraktem przez osoby wykluczone społecznie. Analiza została przeprowadzona za pomocą badania opinii osób wykluczonych społecznie zarejestrowanych w Miejskim Urzędzie Pracy w Płocku. W analizie uwzględniono wyniki ankiet otrzymanych od 350 respondentów, w tym 195 osób ankietowanych za pomocą kwestionariuszy papierowych oraz 155 osób ankietowanych za pomoca kwestionariusza zamieszczonego w Internecie w 2018 r. Analizy obejmowały rozkład odpowiedzi na pytania ankietowe w całej próbie wraz z weryfikacją 
istotności statystycznej między odpowiedziami, a takimi zmiennymi jak: płeć, wiek, wykształcenie I okres rejestracji w Miejskim Urzędzie Pracy.

Słowa kluczowe: praca nierejestrowana, osoby wykluczone społecznie, badania opinii JEL Codes: E24, E26, J46

Information about author:

Mariola Szewczyk-Jarocka, dr

Mazowiecka Uczelnia Publiczna w Płocku

Pl. Dąbrowskiego, 2, Płock, Polska

e-mail: m.szewczyk-jarocka@ mazowiecka.edu.pl ${ }^{1}$

ORCID: 0000-0001-9048-9513

${ }^{1}$ Scientific research carried out under the research grant - the task "Cooperation with universities" City Hall of Płock. 